Colloquia Litteraria

UKSW

$4 / 2017$

SŁAWOMIR RZEPCZYŃSKI

\title{
NORWID AND MODERNITY (A PERSPECTIVE OF SUBJECTIVITY)
}

\section{INTRODUCTION}

Norwid's philosophy, and his creative activity which reflected it, were directed towards the future. His reflection on man and the world was subordinated to the process of the return to the lost union with the Absolute, while history, in his vision, was derivative of man's fall and simultaneously a goal to fulfil and a chance to regain what was lost. In this context each contemporaneity was valued positively if it transcended itself and enabled the move to the next stage, which would bring closer the moment of regaining primordial unity. (Przeszłość, Socjalizm/ "The Past”, "Socialism”). However, such a simple evolutionary approach, according to which what came later was, in a sense, better than what had come earlier, did not form the core of Norwid's thinking. History is not a simple ascending line. On the contrary, it is a muddled line, full of turns and loops. What is more, as Norwid insisted, in some periods the heritage of earlier periods had been lost. What came later was on many occasions valued as lower than what had come earlier. That is why Norwid's thinking about history was a search for such achievements which ennobled man above his everyday existence and mortality, and allowed him to recognize himself in the perennial perspective. Therefore, not each object of his fascination was new, modern and novel, and not all which was old was an object of his contempt. Each element from the 'time axis' was referred by him to the ultimate value; also what had been 
past could in his system of values be perceived as more modern than what was contemporary.

It is no wonder, then, that literary historians from the beginning of their focus on Norwid had problems with assigning him to one particular period. Such expressions as 'a late Romantic', 'a forerunner of the Positivists', 'a symbolist', 'a Parnassist', (but also 'an aristocrat, 'a democrat, or 'a Catholic poet') did not reflect fully his philosophical, social and artistic ideas. He was, at the same time, in the mainstream and on the fringes; he was a part of the mainstream and reflected on it from a distance.

\section{What Kind of Modernity?}

The notion if modernity is not obvious. ${ }^{1}$ It could be understood in at least two ways. Firstly, modernity could be connected with

1 Hans Rober Jauss listed three thresholds in the literary process of modernism. He called the first of these, the 'aesthetic revolution' which was started in Germany in the period of the classical-Romantic threshold, which changed the direction of historicism, rejecting Antiquity with its norms of beauty and-in reference to the concept of Rousseau's natural education-defined a new place for art and new functions for it. The second threshold happened in the middle of the nineteenth century, and Jauss connected it with the ideas of Baudelaire, who based his new aesthetics on the concept of 'the lasting beauty' and with Flaubert's concept of 'fragmentary perception'. Jauss stressed the transition from historicism to aestheticism, which draws the past in the area of 'a museum of imagination'. Jauss placed the third threshold around the year 1912, and connected it with Apollinaire. He stressed that its distinguishing feature was a drive toward a 'phantasmagorical future' and rejection of all the past. H. R. Jauss, Proces literacki modernizmu od Rousseau do Adorna, in Odkrywanie modernizmu. Przekłady i komentarze, ed. by R. Nycz, Kraków 1998, 21-70).

Therefore, such an understanding of modernism as a chain of changes started in the eighteenth century, which continued in the nineteenth century and the beginning of the twentieth century. Such a period includes different cultural movements, from the Enlightenment to avant gardes of the twentieth century, and modernism in this sense is more of a process, a chain of changes, a dynamic of moving away from certain traditions, but also a dynamic of the return to some and constructing of some other visions of man and the world, up to a rejection of all bases on which the pre-modern world had been constructed.. 
contemporaneity, with what is against some form of the past, from which it breaks in this way or another. In this sense each period is modernity in the context of the past, which belongs to what is gone. Such an approach would be, de facto, non historical and would stress the awareness of being associated with a new period which has overcome what dominated in the past. ${ }^{2}$ Secondly, the notion of modernity functions as a certain period in the historical process and is contrasted with the tradition based from Antiquity till the threshold in the awareness which took place in the postCartesian period, mostly in the eighteenth century and survivedwith appropriate modifications - to the beginning of the twentieth century. Modernity is also defined as modernism (although the latter term is often used to describe phenomena which started in the second half of the nineteenth century).

Therefore, modernity would be a term which stresses the process of 'disenchantment' Entzauberung der Welt) - to use a term proposed by Weber-of the world in which man is no longer understood as its 'function'. On the contrary, it is the world which becomes 'a function' of man, now placed in its centre in the place earlier ascribed to God. In this way the concept of subjectivity was born, the essence of which is a drive to rule the world and construct the foundations of one's own existence, taking control over social, political and economic processes, building a new order in place of the dethroned order inherited from the pre-modern period (The French Revolution is a clear example here). The modern 'I' includes in itself: self-knowledge of the Cartesian cogito, rationality of the absolute rule of the Enlightened reason, Kant's transcendental cognitive 'I' and, finally, Fichte's I-hood. In this order we can observe the process of the breaking of the 'I' from the absolute, to which it was subordinated and the beginnings of a new attitude, on which a new (modern) order of things is to be founded.

Modernity enters all spheres of life, reifying the world, and the dispersion of the world follows as a result, separated from

\footnotetext{
2 See, on this, Paul de Man, Liryka i nowoczesność. Transl. by A Przybysławski, „Literatura na Świecie” Nr 10-11/1999, s146-169.
} 
the sphere of the sacrum, dissolution of the mythical connection with the primordial, the loss of holistic vision, its internal connections and rules, of seeing reality-to use Blake's phrase- "in a grain of sand".

\section{Norwid's Modernity}

Norwid's creative activity began in the 1840 s, when the Romantic attempt to react to eighteenth century modernity (pre-Romantic and early Romantic) had already subsided, while the new, late Romantic, or even post-Romantic awareness of the spent nature of the period's paradigms started to dawn. This process, as is known-was different in different European countries. In Germany it happened at the turn of the eighteenth century; in other countries, including France, where Norwid lived for a long time, it lasted till the 1850 s. $^{3}$

The essence of early Romantic modernity-that is the one with which Norwid was confronted-could be briefly summarized in the manner of H. Remak:

Romanticism is an attempt to put together a broken universe; it is a painful experience of dualism, and simultaneously an attempt to find rescue in organic monism; it is a crush with chaos, which was accompanied by the will to include it in the cosmic order; it is an attempt to unite contradictions, to create synthesis through antithesis. ${ }^{4}$

On the one hand, we have a 'broken universe', 'dualism', 'chaos', 'contradictions; on the other, attempts to unite, to drive towards 'monism', 'the cosmic order', uniting contradictions. For Romantics, 'disenchantment' of the world was the loss of the old unity and the desperate attempt to regain it. They tried to find such categories

3 Romanticism is sometimes treated as a reaction to the so called radical Enlightenment, which places it in the specific position as a counter proposal to Enlightenment modernity. See A. Bielik-Robson, Inna nowoczesność. Pytania o współczesna formułę duchowości, Kraków 2000.

${ }^{4}$ H. H. H. Remak, Klucz do zachodnioeuropejskiego romantyzmu, „Pamiętnik Literacki" 1978, (3) 199, 
which would take off man the burden of despair, pain, loneliness and loss, and which were doomed-this is not a good moment to argue why was it so-to failure.

In his early period Norwid tended to go along with general Romantic tendencies to define the situation of man in a 'disenchanted' world (we could analyse his first poems in this manner: Samotność ("Loneliness"). Mój ostatni sonet ("My Last Sonnet"), and also the socalled 'black suite' or Epos-nasza ("Epic-Ours"). And in his attempts to regain the connection with the lost transcendence (the dramas Krakus and Wanda). From a certain perspective these texts could be perceived as melancholic, both in the cultural and private aspects. This melancholy, being a result of longing for the ideal world (that is such a world as in the poem Moja piosnka II ("My Song II"), should be connected with all his writings, so that we could see three of his projects/trends: turn towards a religious outlook, temporal hermeneutics and idealization. Simultaneously, they were three projects of Norwid's modernity postulated and accomplished in his writings in opposition to the radicalism of the Enlightenment and to the 'traditional' understanding of Romanticism.

Remembering the fact that Norwid declared that he was an artist and a writer, it should be stressed that his artistic activities were for him a fundamental tool to fulfil these three projects, and this was accompanied by the awareness of the fact that he was "not of his time", proposing solutions not for his but for future generations (for example, in the ending of the poem [Klaskaniem majac obrzękłe prawice...] ("The People's Hands Were Swollen with Applause"), the project of "the art of the future" in Promethidion, "a new building of aesthetics' in Białe kwiaty ( "White Flowers"). Being "not of his time" also has a past aspect. It means "too early", but also "too late", hence Norwid's attempts to enliven certain past traditions which were seemingly spent. However, they were the elements of a nostalgic, 'enchanted' world Norwid was recalling, and the return to them could, according to Norwid, regain the contact with the lost transcendence. The list of such references is long: it is opened with the Bible and ends with the achievements of "the Greats", whom Norwid many times 
included in the streams of great traditions (for example, Mickiewicz and Słowacki were for him writers in the stream of the Christian epic, which was characterized by man's connection with God and which was simultaneously desired and lost, and therefore, in the nineteenth century, particularly in the second half of this century, already impossible).

\section{Poetry, Poet, Author (the Strong 'I' as a Reaction to the Weakening of a Poet's Social Function)}

At the core of Norwid's thinking about poetry there was a wholly Romantic conviction that poetry is a primordial way of man's expression, that it is a kind of proto-language in which the act of 'voicing' is performed in a perfect way. Norwid's hermeneutics was built around the person, who on the one hand expresses one's own understanding and feeling 'I', and on the other, subordinates this 'I' to the category of a higher order, a guarantor of order. In the face of post-Cartesian 'disenchantment' with the world, the dissolution of myth and burdening man with the mission of organizing earthly reality in the spirit of atheism or theism, and also in opposition to reform movements challenging the Christian tradition (or being 'subcutaneous' within this tradition) Norwid tried to connect the integration of ' $\mathrm{I}$ ' (in the sense of the rhetorical speaking 'I') with the 'fideistic' 'I' subordinated to supra-individual absolute categories.

In "Milczenie" ("Silence") from 1882 Norwid showed the concept of the change of forms of self-expression in the historical perspective: from the psalm-like participation in the absolute, lost as a result of man's fall, to the contemporary period of the romance-novelistic fall. He relied in his concept on Giambattista Vico's figure of ricorso. In this way the Romantic myth of the return of man to the starting point, to the lost cosmic unity, was realized in Norwid's writings, which connects Norwid with such Romantic-Modern thinkers as Goethe, Novalis, Schelling, Hegel and others. This concept, which Norwid connected with the Christine doctrine (mostly through reference to the Bible story of original sin and of the fall of primordial people, for example in the poems such as: Przeszłośćl“The Past”), 
Socjalizm/"Socialism", ironic Kółko/ "A Small Circle"), was fundamental in his thinking. Through its 'ideological' ties with the Biblical tradition it meant the acceptance of the concepts fundamental for Romanticism, but at the same time it was also a 'trans-Romantic' 'idiolect' of Norwid. It inscribed Norwid in the Romantic ethos of melancholy, but simultaneously distanced him from it through his search for ways of 'combating' its dangers. ${ }^{5}$ ${ }^{6}$ He searched for these ways not so much on the level of earthly existence, but through 'the glance up' (for example in Assunta, with its references to Malczewski's Maria). The totalisation of his lyric poetry connects Norwid with the concept of it as a superior mode of Christian expression as proposed by Friedrich Schlegel. I have in mind not so much the direct genetic relationship of Schlegel with Norwid, but the similarities in their Romantic worldview as a reaction against the Enlightenment's rationality of the world. Norwid, in his Romantic dream of the return to the primordial world of myth and unity of man with the Absolute, included in this vision pictures of prefigurations of Christianity. Such is the case of both Krakus and Wanda, where mythic events gain the status of reality because they anticipate the future in its soteriological and tragic aspect. ${ }^{7}$ The tragedy of Krakus and Wanda should be referred to Christ's sacrifice, as was the case with the contemporary martyrdom of the Polish nation (although Norwid distanced himself from the national Messianic tendencies, particularly the ones proposed by Mickiewicz). However, Norwid did not have in mind a cyclic necessity of such carnage. The flow of time should make sacrifices unnecessary, and that is why he pushed forward the idea of 'making martyrdom unnecessary', that is of not wasting the achievements of the past (in most cases treated by him

5 See my sketch Melancholijny liryzm Norwida, op. cit.

6 E. Kasperski wrote about it in Dyskursy romantyków. Norwid i inni, Warszawa 2003, 53-54.

7 A fragment from the introduction to Krakus is worth quoting here: "I personally believe that the tragedy is a showing of historical or social fatality specific for a particular nation or period." Cyprian Norwid, Pisma wszystkie, ed by Juliusz Wiktor Gomulicki, vol. I-XI, Warszawa 1971-1976; here IV, 161. 
in a representative manner, for example, in "Coś ty Atenom zrobił Sokratesie" ("What Have You Done to Athens, Socrates")).

The diagnosis of 'disenchanting of the world', understood in the sense of moving the activity from the Creator to man and the process of reification that went along with it, for Norwid meant the idea of accepting the sacrifice and-according to his almost ever present metaphor-following after the Saviour with one's own cross. Myths were real to him both in the temporal sense-of the presence of the past in the present-and in the 'spatial' sense-of the inter penetration of the mystic with the real; reflection of what is holy in what is every-day, ordinary, the connection of the high with the low (as in the metaphor that "God also lives in the garbage").

Therefore, the place of contemporary man is given by the primordial fall; man has been given a chance to return to the lost state of happiness, but has not taken it. History was for Norwid a process of upsurges and returns, ups and downs, progress and regression. The negative picture of contemporary man Norwid created was connected with the rejection of everything that transcends the material sphere, which does not have a pragmatic dimension in everyday existence, and does not lead to instant success (for example in the short story Tajemnica lorda Singleworthal "Lord Singleworth's Mystery"). Contemporary man, by rejection of the transcendental perspective, draws a tiny space for his life, his "small circle" ("A Small Circle") where he moves with his back to the external word. It was not only the critique of the contemporary lowering of man's gauge, but also the presentation of the world given to the rule of a greedy, personal 'I', which in its drive to rule over everything wants to build its paradise on earth. Modernity creates an 'I' separated from transcendental categories, harnessed to every-day reality, subordinating the world over which it wants to rule with its own rules. It puts itself in the centre, ignoring everything around it, and at the same time sentencing itself to suffering in challenging all adversities against which it feels helpless. Therefore, in order to remove this suffering it functions in the circle of its own everyday reality or changed in a mechanical ritual inherited, but no longer understood, traditions (pictures of the formal fossilization of sacraments or losing the sense of fasting in Bransoletka/ "A Bracelet"). 
'I' removes away from itself not only religious categories, but also all kinds of subordination to ideals of social, political, national or family life. Art also loses its transcendental dimension and appears as "knickknacks", dingbats of every-day reality, or an object of commercial activities (Cackal "Knick-Knacks", "Ad Leones!). Norwid made this modern 'I' serve as negative protagonists of his texts, including it into ironic contexts and contrasting with-mostly taken from the tradition the form of the positive fulfilment of ' $\mathrm{I}$ '.

Norwid's artistic output was a form of self-expression which is obvious after Romanticism's artistic revolutions. It was a discourse about the world from the perspective ' $\mathrm{I}$ ', the construction of the strong subject, who will be rewarded with knowledge of the truth, who was (as in Romantic concepts of a poet) elected („Boży-palec zaświtał nade mną”/ "God's finger shone above me" from the poem Klaskaniem...) and wants to fulfil its mission in a strong, authoritarian voice. But this voice was not grounded only in the fact of election (then it would be transferred to the sphere of mysticism), but also the authority of knowledge gained through individual reading and thinking, of gathering of all tradition and-as he put it himself-a testimony of many centuries of history. One of the key ways of argumentation used by Norwid was to strengthen his own position through the authority of his predecessors. "The used ones" as authorities, who were given the chance to reach the truth, they became figures who were conventionalized by Norwid as kinds of icons, and he consistently put himself among them. ${ }^{8}$ In this way the subjective 'I' was not only the voice of self-expression of an individual poet; it was a voice from the perspective of "the heights of history" (To rzecz ludzkal "It Is a Human Thing"), a voice which appropriates all tradition to use it against the degenerated contemporaneity, which is presented very consistently in Norwid's writings as the misappropriating of values (for example in Vade-mecum. Ostatni despotyzm, Cacka, Nerwy, Larwa; short stories: Bransoletka, Cywilizacja).

${ }^{8}$ See my sketch „Lecz ty, lecz ja. Gra sygnatur w „Fortepianie Szopena”, in S. Rzepczyński, Biografia i tekst. Studia o Mickiewiczu i Norwidzie, Słupsk 2004, 158-179. 
Therefore, in Norwid's lyric poetry we have the case of the creation of the dual 'I'; from beyond the self-expressive individual voice there appears the objectified ' $I$ '. In this way, in his poetry a play between both creations of the subject existed, a concrete voice (usually of a participant in a presented world) is transformed into a voice telling the truth ex cathedra. ${ }^{9}$

Norwid was aware that in the nineteenth century the voice of a writer (and he regarded writing as a profession with a unique social role, which should be rewarded by the society, including through decent pay) was getting weaker, and its function was being transformed: it was no longer a voice of authority (religious, moral, political), it was being pushed aside to accept the role of a chronicler of its own period, or a provider of entertainment. Works no longer expressed values; they became commodities (“Ad Leones!”) Being aware of the weakening of an artist's (conjurer's) voice Norwid tried to find ways to bring the power back, and that is why he introduced procedures of figural allegories, trying to strengthen the authority of a contemporary writer with many centuries of the long community of people telling the truth and simultaneously being in conflict with their contemporaries ("What Have You Done to Athens, Socrates...").

Michał Głowiński presented one more way in which Norwid strengthened his auto-expressive 'I', that is through the category of the lyric "You", Norwid's "second person". Głowiński connected it with the dialogic aspect of Norwid's poetry: a "poetry of ceaseless discussion". This "second person" is no one specific, is not concrete; it is either an opponent to a textual 'I', or, as Głowiński claimed, "the second role of the poet". In such poems it is not a "ready-made truth" which is presented, but a process of attaining it. A kind of doubling oneself (it should be added that in the case of some texts this is even more than 'doubling'). It constructs a type of ' $\mathrm{I}$ ' which is, from a certain perspective, not obvious. As a result, however, the play with personal categories strengthened the power of persuasion of the authorial 'I',

\footnotetext{
9 I wrote about it in the context of Norwid's short stories in Wokó nowel włoskich Norwida. Z zagadnień komunikacji literackiej, Słupsk 1996.
} 
and the truth is pronounced, in this rhetorical process, in a stronger fashion and is regarded by 'I' as indisputable. Głowiński also wrote that Norwid's construction of "the second person" was connected with such forms as the exemplum and the parable; however, Norwid treated these traditional forms in a non-traditional way, because he did not differentiate between these two forms and did not use didactic preaching in stanzas directed to the second person. The whole communicative situation is offered for a reader to consider. This reader has to follow the process of attaining the truth and consider the power of used arguments to build his own judgements. However, the way of existence of the truth presented by 'I' is so strong that we could speak here about a certain 'steering' of the process of perception, which means that the arguments of 'I' are discretely forced onto a reader, but this process is preceded by provoking him/her to consider the presented issues seriously.

Let us observe that the forms of expressions of Norwid's 'I' were not, or at least, were not predominantly, expressions of emotions, a feature rightly attributed to Romantics. The subject of auto-expression is an intellect using ideas which are expressed in a poetic-rhetorical manner (as Poetry and Expressions - Ogólniki/ "Generalities"). The sense of the lack of comfort connected with the lack of respect of the values important for Norwid both at the individual and social levels was a source of intellectual emotions and poetic imagination. He had to think about a way of constructing an 'I' which would reject sentimental emotionality and the Romantic storm of emotions, and which would 'reincarnate' forms known from the tradition and put them into new contexts, adapt them to new needs.

The ways of 'strengthening 'I'" presented could be described as the 'contextualisation' of a subject. In this way Norwid started the process of the depersonalisation of a speaking subject. ${ }^{10}$ We would obviously answer the question "Who speaks?" with 'I' [speak]. But

10 This is one of the most important features of contemporary poetry shown by H. Friedrich in his musings about w jego rozważaniach Baudelaire: see, H. Friedrich, Struktura nowoczesnej liryki, op. cit., 58-61. 
this is 'I' written into many personal categories, recalled in an iconic manner: either as authorities, into which Norwid's 'I' is inscribed, or as 'I' split in the process of a dialogic demonstration of attaining the truth. In this, the ' $\mathrm{I}$ ' located inside the text is transformed into the "Over I" of the one who has attempted to search for the truth and has either found it, or has been convinced of the necessity to search for it, and provokes joint thinking about it in which he wants to be a guide. As a victim of the world of modernity, a victim of his own being 'beyond times', he constructed his aristocratic 'I' (of which he was accused by Krasiński). The basis for this aristocratic stance was different both in the context of Norwid's private sphere and in his textual constructions and auto-constructions.

The subject's depersonalization and his contextualizationas we may, therefore, presume-were in Norwid's intentions to strengthen the voice of his speaking subject. We know that in the social context his attempts were not successful. His voice was perceived as that of a marginal freak. Norwid's depersonalization and contextualization revealed their duality, their double-edged aspect: what was to strengthen the integrity of the speaking 'I' and make the proclaimed truth clearer turned out to be one more instance of 'beyond times'. It was only later in modernity that Norwid's ways of creating a subject were accepted; as well as his proposals to transform poetics. ${ }^{11}$

11 It was only when I finished this paper that I read a book by Wiesław Rzońca, Norwid a romantyzm polski (Warszawa 2005), in which a pre-modernist character of Norwid's poetics was described. 